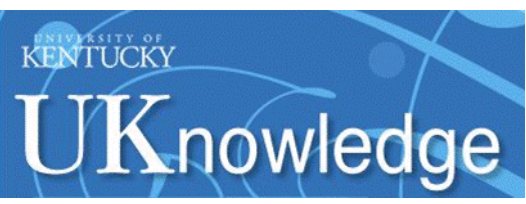

University of Kentucky

UKnowledge

$9-2015$

\title{
How Unique is the Service Leadership Model? A Comparison with Contemporary Leadership Approaches
}

\author{
Daniel T. L. Shek \\ University of Kentucky \\ Po P.Y. Chung \\ Hong Kong Institute of Service Leadership and Management, China \\ Hildie Leung \\ Hong Kong Polytechnic University, China
}

Follow this and additional works at: https://uknowledge.uky.edu/pediatrics_facpub

Part of the Pediatrics Commons

Right click to open a feedback form in a new tab to let us know how this document benefits you.

\section{Repository Citation}

Shek, Daniel T. L.; Chung, Po P.Y.; and Leung, Hildie, "How Unique is the Service Leadership Model? A Comparison with Contemporary Leadership Approaches" (2015). Pediatrics Faculty Publications. 209. https://uknowledge.uky.edu/pediatrics_facpub/209

This Article is brought to you for free and open access by the Pediatrics at UKnowledge. It has been accepted for inclusion in Pediatrics Faculty Publications by an authorized administrator of UKnowledge. For more information, please contact UKnowledge@lsv.uky.edu. 
How Unique is the Service Leadership Model? A Comparison with Contemporary Leadership Approaches

\section{Digital Object Identifier (DOI)}

https://doi.org/10.1515/ijdhd-2015-0403

Notes/Citation Information

Published in International Journal on Disability and Human Development, v. 14, no. 3, p. 217-231.

(c) 2015 Walter de Gruyter GmbH, Berlin/Boston

The copyright holders have granted the permission for posting the article here. 


\section{Daniel T.L. Shek*, Po P.Y. Chung and Hildie Leung}

\section{How unique is the service leadership model? A comparison with contemporary leadership approaches}

DOI 10.1515/ijdhd-2015-0403

Received April 5, 2014; accepted June 1, 2014; previously published online August 12, 2015

\begin{abstract}
The growth of the service economy in the contemporary world has resulted in a different set of requirements for effective leadership as compared with the industrial era, which focused primarily on manufacturing industries. To nurture "service leaders" in the service economy, the Hong Kong Institute of Service Leadership and Management proposed the service leadership model. The key characteristics of the service leadership model are outlined in this paper. A systematic comparison was also conducted to identify the common and unique features of the service leadership model with reference to the existing leadership theories, including the trait, servant, spiritual, authentic, ethical, transformational, charismatic, and top-down leadership approaches. The limitations and future directions for research in service leadership are also presented.
\end{abstract}

Keywords: authentic leadership; charismatic leadership; ethical leadership; servant leadership; service leadership; spiritual leadership; transformational leadership.

${ }^{*}$ Corresponding author: Professor Daniel T.L. Shek, PhD, FHKPS, BBS, SBS, JP, Associate Vice President and Chair Professor of Applied Social Sciences, Department of Applied Social Sciences, The Hong Kong Polytechnic University, Room HJ407, Core H, Hunghom, Hong Kong, P.R. China, E-mail: daniel.shek@polyu.edu.hk; Centre for Innovative Programmes for Adolescents and Families, The Hong Kong Polytechnic University, Hong Kong, P.R. China; Department of Social Work, East China Normal University, Shanghai, P.R. China; Kiang Wu Nursing College of Macau, Macau, P.R. China; Hong Kong Institute of Service Leadership and Management, Hong Kong, P.R. China; and Division of Adolescent Medicine, Kentucky Children's Hospital, University of Kentucky, Lexington, Kentucky, USA Po P.Y. Chung: Hong Kong Institute of Service Leadership and Management, Hong Kong, P.R. China

Hildie Leung: Department of Applied Social Sciences, The Hong Kong Polytechnic University, Hong Kong, P.R. China

\section{Introduction}

The shift from the industrial to post-industrial economy calls for the development of a leadership model that caters to the constantly changing needs [1]. With reference to the growing emphasis on service, the service leadership model was developed by the Hong Kong Institute of Service Leadership and Management. The purpose of the present paper is to briefly outline the service leadership model and compare it with existing leadership theories and approaches, including trait approach, servant, spiritual, authentic, ethical, transformation, charismatic and top-down leadership approaches, by delineating their similarities and distinctions.

According to Chung [2], service leadership “...is about satisfying needs by consistently providing quality personal service to everyone one comes into contact with, including one's self, others, groups, communities, systems, and environments. A service leader is a ready, willing and able, on-the-spot entrepreneur who possesses relevant task competencies and is judged by superiors, peers, subordinates, and followers to exhibit appropriate character strengths and a caring social disposition". Chung argued that effective service leadership is a function of moral character, leadership competencies, and a caring disposition. In addition, Chung [3] proposed 25 principles of service leadership that serve as a framework for those who are interested in understanding how to provide high quality service and managing service. Chung [4] also identified 12 dimensions in relation to our personal brand, highlighting the desirable qualities of leadership under the service economy. The 12 dimensions are categorized into four domains, including doing, thinking, being, and growing. The key characteristics of the service leadership model are outlined below.

1. Service orientation (self and others): It is proposed in the service leadership model that "true leadership is a service aimed at ethically satisfying the needs of one's self, others, groups, communities, systems, and environments" [1]. The individual needs of leaders are also considered because "a leader is unable to optimize his 
or her ability to lead others well unless he or she is healthy in mind, body, and spirit" [1].

2. Systems orientation (self, followers, habitat, and larger system): As there are inter-relationships among different systems, a multi-level systemic approach is adopted in viewing leadership and designing a leadership training curriculum. These systems include the individual, follower, group, and environmental systems. Furthermore, service leaders are responsible for the immediate habitat (i.e. environment and culture) of the service organization. They must closely monitor and maintain the health of the service habitat [3].

3. Leadership competencies: Excellent service is dependent on service leaders' competencies (i.e. one's ability to apply knowledge and skills in productive and meaningful ways) [4].

4. Moral character: Service leaders must serve by knowing what is right and by acting in moral ways at all times. A service leader should exhibit positive ethical traits, such as honesty, reliability, integrity, respect, and willingness to work with others [3].

5. Caring disposition: Effective service leadership is characterized not only by a service leaders' competencies and moral character, but of equal importance is a caring disposition, such as showing sincerity, consideration, empathy to those one serves, and listening and attuning to their needs [3].

6. Personal qualities of a leader: According to Chung, "the server is the service", which implies that the personal qualities and traits of leaders determine how successful the service delivered will be. As such, leaders' personal qualities are the "core" content of service [5].

7. Everyone is (can be) a leader: Service leadership stresses that "everyone is a leader for at least $15 \mathrm{~min}$ every day" [2]. Specifically, "several times each day, every human being occupies a position of leadership and possesses the potential to improve his leadership quality and effectiveness" [3].

8. Self-leadership: "Service includes self-developement efforts aimed at ethically improving one's competencies, abilities, and willingness to help satisfy the needs of others" [2]. It is believed that if one can lead him/herself in positive, productive, and healthy ways, it is the best indication that he/she can also lead others [3].

9. The need for continuous improvement: Service leadership is about "constantly striving to provide the highest quality service one affords to everyone one comes into contact with and whose lives are affected by one's actions or leadership" [2]. Service leaders must engage in constant reflection on one's character and service provision in order to seek for continuous improvement both professionally and personally [5].

10. Mentoring followers: Service leadership theory values mentor-apprentice models as these professional relationships enable learning and sharing of experiences, thus enabling followers to master knowledge and skills in ways that help build their efficacy [3].

11. Chinese cultural values: The service leadership model has a "succinct mention of Buddhism, Confucianism, and Taoism... (with the) effort to help East meet West" [5, p. 58]. Teachings pertain to self-control, inner peace, recognition and avoidance of vices, concern for others, coping, and the bigger systems one is situated in.

12. Comprehensiveness and breadth of the model: The service leadership model is comprehensive as it places equal emphasis on the emotional, behavioral, cognitive, spiritual, and physical dimensions of a service leader. This is evidenced by the 12 dimensions of service leaders' personal brand categorized as doing, thinking, being and growing dimensions, which fully encompass elements essential for successful service leadership [4]. Its focus is broad as it covers not only a single dimension in leadership (e.g. traits) but also the competencies, moral, and caring dimensions of leadership. Furthermore, it is multidisciplinary in nature, which bridges and encompasses leadership concepts from a wide range of academic disciplines, including psychology, economics, sociology, and anthropology [2].

The 12 dimensions of the quality of service leadership are explained below.

1. Functional: Expertise dimension - This dimension addresses what service leaders do to make a living and contribute to society. This dimension is typically what companies use to decide on who they should hire. That said, there are a growing number of companies finding that hiring based only on functional competence is not the best way to get the brightest people to the team.

2. Visual: Daily management dimension - This dimension includes what service leaders look like, be it from the clothes they wear, hair style, accessories and everything else related to his or her fashion. This is worth thinking about because it is their best interest to have the kind of visual position that fits and reinforces their personal brand. In other words, one's visual presentation should reflect who the leader is, what they do, and what they aspire to become. This consistency helps reinforce the projection of influence. 
3. Physical: Health dimension - This dimension must be stable in order for a service leader to succeed, although there are cases when dedication and commitment have pushed through to achieve greatness. On the one hand, a service leader who is perceived as consistently healthy and vibrant may be easier to attract others. On the other hand, a leader who is consistently perceived as unhealthy or sickly may face having this perception take over his/her personal brand, putting the leader at a possible disadvantage.

4. Mental: Intellectual dimension - This dimension includes one's intelligence and ability to think critically and logically. This can involve the ability to debate ideas with others or oneself, and even make hypotheses and thought experiments that test new ideas. This dimension is the service leader at his or her intellectual best, allowing them to connect with others who are responsible for problem-solving and then explore solutions to tough challenges.

5. Emotional: Happiness dimension - This dimension is diverse and everything the service leader does will thrive or crumble depending on his/her emotional state. The catch-all notion of "happiness" is used to refer to an optimal state in this dimension.

6. Economic: Security dimension - This dimension proposes that it takes a certain level of wealth or security in order for a service leader to be able to move and take action.

7. Spiritual: Habitat dimension - The content of this dimension is seen as subjective and personal. In the model, it can refer to a service leader's religious beliefs, but is more about what connects him or her to things that are bigger than their immediate selves. Thus, this dimension can include religious practice, the commitment to the environment, or anything outside the immediate, physical world.

8. Moral: Character dimension - This dimension includes the metaphysical quality about the service leader that cannot be seen or strictly defined, but which informs what he or she does and is perceived by others. The model proposes the secular moral qualities defined by the British Association for Counselling and Psychotherapy (BACP). However, whether it's Confucius, Benjamin Franklin or the BACP, some of the details may vary but the essential ingredients of this dimension seem to be universal. Some of the qualities are empathy, sincerity, integrity, resilience and others.

9. Care: Compassion dimension - This dimension is considered critical for creating a sustainable, positive and lasting personal brand. This could be extended over all the dimensions, in that the people in the service leader's life may not be inspired or may not even extend the trust needed if they don't feel the service leader has compassion for what others experience.

10. Social: Relationship dimension - This dimension includes the facets of the service leader that causes others to seek them out for interpersonal connection and because the service leader is considered socially valuable. Having a strong relationship dimension means the service leader is considered funny, knowledgeable, compassionate, having contributions to the group's happiness, and is perceived as a strong influencer.

11. Leadership: Trustworthiness dimension - Everyone involved in service provision should have the capacity to make decisions appropriate to their situation. At any given moment, unique pressures call for leadership and decision making that is situational. One's leadership is balanced against their trustworthiness, and together they can elevate the service leader's brand to excellence. In service leadership, strengthening this dimension means developing one's competence, character, and care, but for that to happen the service leader must be self-aware. By being aware of the importance, ingredients and paths to leadership, this awareness - followed up with action - is a strong path towards strengthening this dimension.

12. Lifelong learning: Maturation dimension - This dimension addresses the service leader's commitment to continuously improve their education and knowledge. By upgrading one's skills and knowledge through lifelong learning, the service leader can always provide a better and broader set of skills and information to the people around them.

Where the 12 Dimensions can be applied by service leaders as a checklist to strengthen the quality and sustainability of their leadership, the Service Leadership model hinges on two critical elements, character and care. The content of the service leader's character are both the positive qualities expressed by the traditional Confucian values or the BACP list. More importantly, a service leader must take into account the presence of the "anti-values" or the negative opposites of the listed values. For example, although empathy, sincerity, integrity, and resilience are considered important, their opposites are considered "viral" qualities that can directly weaken a service leader's effectiveness. Therefore, service leaders must watch out for and purge qualities like indifference and apathy, insincerity, corruptibility or inflexibility. 
A service leader with healthy and positive moral standards may not attract others, but unhealthy and viral moral standards can certainly repel others. Leaders may be able to lead others temporarily because of their skills (communication, strategic thinking, tactical or financial skills), but their leadership is unlikely to sustain. According to the service leadership model, a leader's moral standard and character do not seem important until that leader loses his or her moral authority.

Similarly, care plays a critical role in service leadership not because of its importance, but because the undesirable quality of indifference or cruelty impedes leadership effectiveness. Caring and compassion are the emotional energies that strengthen human relationships; they draw people together and endear people to one another, which is crucial in a service setting.

\section{Comparing the service leadership model with contemporary leadership models}

A summary of the major components and propositions of respective leadership theories can be found in Table 1, while results of comparisons between service leadership and other contemporary leadership theories are found in Table 2.

Table 1: Summary of major components and propositions of leadership theories or approaches.

\begin{tabular}{|c|c|}
\hline Leadership theory or approach & Major components and propositions \\
\hline Service leadership & $\begin{array}{l}\text { - Effective service leadership is a function of leadership competencies, moral competencies, and } \\
\text { caring disposition. } \\
\text { - Everyone is (can be) a leader. } \\
\text { - Service leaders engage in self-reflection and -leadership to ensure that high levels of service are } \\
\text { provided to satisfy needs of self, others, groups, communities, systems, and environments. } \\
\text { - Chinese cultural values inform service leadership theory. }\end{array}$ \\
\hline Trait approach to leadership & $\begin{array}{l}\text { - Leaders and non-leaders are differentiated based on a set of identified abilities, traits, and } \\
\text { characteristics. } \\
\text { - Leaders are born and not made. }\end{array}$ \\
\hline Servant leadership & $\begin{array}{l}\text { - Servant leadership occurs when leaders assume the role of servants in their relationship with } \\
\text { followers. } \\
\text { - Leadership behaviors are motivated by leaders' inherent drive to serve. } \\
\text { - Needs of followers precede leaders' individual needs. }\end{array}$ \\
\hline Spiritual leadership & $\begin{array}{l}\text { - The major components of the model include altruistic love, faith and hope. } \\
\text { - Spiritual leadership is achieved through leaders' creation of vision. } \\
\text { - The value of transcendence motivates spiritual leaders to place needs of followers above one's self- } \\
\text { interest. }\end{array}$ \\
\hline Authentic leadership & $\begin{array}{l}\text { - Authentic leaders demonstrate leadership behaviors that are genuine and reflective of one's } \\
\text { personal values. } \\
\text { - Authentic leaders possess positive psychological capacities of confidence, optimism, hope and } \\
\text { resilience. } \\
\text { - Leadership is based on one's self-concept and reliant on one's level of self-awareness and ability to } \\
\text { engage in self-reflection and -regulation. }\end{array}$ \\
\hline Ethical leadership & $\begin{array}{l}\text { - The ethical leadership model emphasizes moral management and ethical standards. } \\
\text { - Leaders must reflect and monitor one's behaviors to ensure high ethical standards are upheld. } \\
\text { - The ethical leaders' role is to encourage and ensure followers to seek justice and behave morally. }\end{array}$ \\
\hline Transformational leadership & $\begin{array}{l}\text { - Leadership is conceptualized as an influential process that enables and empowers followers to } \\
\text { perform in ways that exceed expectations and become leaders ultimately. } \\
\text { - Transformational leadership is achieved through idealized influence, inspirational motivation, } \\
\text { intellectual stimulation and demonstration of individualized consideration for followers. }\end{array}$ \\
\hline Charismatic leadership & $\begin{array}{l}\text { - Followers perceive leaders as individuals who possess exceptional qualities. } \\
\text { - Charismatic leaders influence followers through compelling idealized visions, displaying } \\
\text { unconventional behaviors, and taking personal risks. }\end{array}$ \\
\hline Top-down leadership & $\begin{array}{l}\text { - Leaders are formally appointed individuals who possess power and authority. } \\
\text { - Leadership is conceptualized as top-down influence and unilateral. } \\
\text { - Decisions are made solely by leaders high in the organizational hierarchy. }\end{array}$ \\
\hline
\end{tabular}


Table 2: Comparison of service leadership theory with leadership theories or approaches.

\begin{tabular}{|c|c|c|c|c|c|c|c|c|}
\hline $\begin{array}{l}\text { Key characteristics of } \\
\text { service leadership }\end{array}$ & $\begin{array}{l}\text { Trait approach } \\
\text { to leadership }\end{array}$ & $\begin{array}{l}\text { Servant } \\
\text { leadership }\end{array}$ & $\begin{array}{l}\text { Spiritual } \\
\text { leadership }\end{array}$ & $\begin{array}{l}\text { Authentic } \\
\text { leadership }\end{array}$ & $\begin{array}{l}\text { Ethical } \\
\text { leadership }\end{array}$ & $\begin{array}{l}\text { Transformational } \\
\text { leadership }\end{array}$ & $\begin{array}{l}\text { Charismatic } \\
\text { leadership }\end{array}$ & $\begin{array}{l}\text { Top-down } \\
\text { leadership }\end{array}$ \\
\hline $\begin{array}{l}\text { Service orientation (self } \\
\text { and others) }\end{array}$ & $x$ & $\Delta$ & $\checkmark$ & $\Delta$ & $\checkmark$ & $x$ & $\Delta$ & $\Delta$ \\
\hline $\begin{array}{l}\text { Systems orientation (self, } \\
\text { followers, habitat, larger } \\
\text { system) }\end{array}$ & $x$ & $x$ & $\checkmark$ & $x$ & $x$ & $\Delta$ & $x$ & $x$ \\
\hline Leadership competencies & $x$ & $x$ & $x$ & $x$ & $\checkmark$ & $x$ & $\checkmark$ & $\checkmark$ \\
\hline Moral character & $x$ & $\checkmark$ & $\checkmark$ & $\checkmark$ & $\checkmark$ & $\checkmark$ & $\checkmark$ & $x$ \\
\hline Caring disposition & $x$ & $\checkmark$ & $\checkmark$ & $x$ & $\Delta$ & $x$ & $\Delta$ & $x$ \\
\hline $\begin{array}{l}\text { Personal qualities of a } \\
\text { leader }\end{array}$ & $\checkmark$ & $\checkmark$ & $\checkmark$ & $\checkmark$ & $\checkmark$ & $\checkmark$ & $\sqrt{ }$ & $x$ \\
\hline $\begin{array}{l}\text { Everyone is (can be) a } \\
\text { leader }\end{array}$ & $x$ & $\Delta$ & $\Delta$ & $\Delta$ & $\Delta$ & $\Delta$ & $x$ & $x$ \\
\hline Self-leadership & $x$ & $\checkmark$ & $\checkmark$ & $\checkmark$ & $\checkmark$ & $x$ & $x$ & $x$ \\
\hline $\begin{array}{l}\text { The need for continuous } \\
\text { improvement }\end{array}$ & $x$ & $\checkmark$ & $\checkmark$ & $\Delta$ & $\checkmark$ & $x$ & $x$ & $x$ \\
\hline Mentoring followers & $x$ & $\checkmark$ & $x$ & $\checkmark$ & $\checkmark$ & $\checkmark$ & $\Delta$ & $x$ \\
\hline Chinese cultural values & $x$ & $x$ & $x$ & $x$ & $x$ & $x$ & $x$ & $x$ \\
\hline $\begin{array}{l}\text { Comprehensiveness and } \\
\text { breadth of the model }\end{array}$ & $x$ & $x$ & $\Delta$ & $x$ & $x$ & $\Delta$ & $x$ & $x$ \\
\hline
\end{tabular}

Key: $\checkmark$, Focal component of model; $\Delta$, Briefly discussed in/slightly applicable to model; $\boldsymbol{X}$, Not discussed in/non-applicable to model.

\section{Trait approach}

Conventional leadership theories are centered on identifying abilities, traits, and characteristics that differentiate leaders from non-leaders. Trait theories of leadership assume that leaders are born and not made [6]. While service leadership theory focuses on satisfying the needs of leaders and followers, and adopts a systemic approach to leadership considering the influences of individual, follower, human systems, and the environment, these ideas are not covered in trait theories, which have been critiqued for overlooking the situational or environmental factors that contribute to leader effectiveness [7].

Due to the criticisms against the trait approach, researchers have moved beyond the identification of traits to include behaviors that determine successful leadership. More importantly, contemporary leadership theorists have begun to embrace the notion that exemplary leadership behaviors can be taught and learnt [8]. For instance, service leadership theory asserts that everyone is (or can be) a leader. Vital service leadership attributes, such as leadership competencies, moral competencies and caring disposition, along with personal qualities, are stressed by the model and it is believed that they can be developed in all individuals. Riegel [9] stated that "human development can only be understood by conceiving the emergence of behavior over time as a result of ongoing exchange between the organism and the environment" (p. 46). The service leadership model is in agreement with the incremental theory of traits viewing them as malleable [10]. Individuals' traits can be changed through interactions with service recipients, other service leaders, followers, and also through self-reflection, as well as one's interaction with the service habitat.

In addition, service leadership also assumes that leadership competencies can be learned. Service leadership focuses on leadership development [11, 12], which refers to personal growth that promotes individuals' leadership potential. Proponents of service leadership deem that leadership capabilities can be nurtured through formal education, participation in programs designed to enhance leadership skills, or through life experiences. As such, leadership development and maturation is a continuous life-long process where knowledge, competencies, and experiences accumulate to perpetuate service leadership growth.

Finally, service leadership adopts a humanistic approach to development which perceives human beings as having choice and free will; human potential is also the focus of the model. Decisions made by service leaders are done through deliberate and conscious self-reflection and dialogue $[13,14]$, and continuous leadership growth is guided by intrinsically motivated self-leadership processes. The service leadership model is also consistent with the propositions of positive psychology and adopts a positive focus on leadership development. These, again, 
are not included in trait approach of leadership. Indeed, the trait approach to leadership is one of the earliest perspectives to leadership and has been developed in the West. Therefore, Chinese cultural values are not a part of the model and its comprehensiveness is also limited.

\section{Servant leadership}

When one considers service as a notion in relation to leadership, the servant leadership model [15] would most probably be the theory that comes to mind. Although at first glance, one would intuitionally equate servant leadership with service leadership, it is of theoretical importance to clearly distinguish the two by highlighting their similarities and differences. According to Greenleaf [15], "The Servant-Leader is servant first... It begins with the natural feeling that one wants to serve, to serve first. Then conscious choice brings one to aspire to lead... The best test, and difficult to administer is this: Do those served grow as persons? Do they, while being served, become healthier, wiser, freer, more autonomous, and more likely themselves to become servants? And, what is the effect on the least privileged in society? Will they benefit, or at least not further be harmed?” (p. 7).

From the above, it can be seen that servant leadership places a great emphasis on whether the needs of followers are met by the leader, which is similar to service leadership's service orientation towards the others. The main difference between the two theories in terms of service orientation is the inclusion of the "self". Indeed, the servant leadership theory has been criticized for its over-emphasis on the needs of followers and negligence of the needs of leaders, which may not necessarily be beneficial to the organization [16]. While "going beyond one's self-interest" is the core defining characteristic of servant leadership [17], service leadership does not put followers' needs above or in expense of leaders' own needs, but rather the mutual satisfying of needs in the co-created service process. It is only when leaders' needs are also satisfied in the service process that continuous development and even self-actualization can be achieved.

In addition to service orientation, service leadership also adopts a systems orientation in the conceptualization of leadership. Particularly, service leadership is concerned with whether service meets the needs of the leader as an individual, the follower/service recipients, the habitat and community one is embedded in. A strong emphasis is placed on how the habitat (i.e. service environment) affects service provision, as well as the development of service leaders, and vice versa. In contrast, servant leadership does not adopt a systemic approach to leadership as it is predominantly concerned with followers' needs and development. In fact, the related literature lacks in-depth discussion on the role that the environment plays on effective servant leadership.

In terms of leadership competencies, Russell and Stone [18] identified nine functional attributes of servant leaders (i.e. operative characteristics of servant leaders which can be observed through leader behaviors in the workplace). These attributes include vision, honesty, integrity, trust, service, modeling, pioneering, appreciation of others, and empowerment. However, they are mainly concerned with the servant leaders' abilities to fulfill leadership responsibilities concerning leaderfollower relationships, whereas the functional expertise emphasis of the service leadership model also involves on-the-job practical skills required for day-to-day operational demands of a service leader. In addition to the leadership competencies, or the functional expertise needed for effective service leadership, such intrapersonal attributes as moral competencies are also valued in the service leadership model. Spears [19] claimed that servant leadership is "strongly based in ethical and caring behavior" (p. 26). However, in his attempt to identify characteristics of servant leaders, moral competence was not listed as one of the 10 defining characteristics (i.e. listening, empathy, healing, awareness, persuasion, conceptualization, foresight, stewardship, commitment to the growth of people, and building community). This is starkly contrasting with the service leadership model, which explicitly highlights the importance of morality among service leaders.

In addition to moral competence, the service leadership model also asserts that service leaders should possess a caring disposition when communicating and interacting with service recipients, by demonstrating sincerity, careful listening, and understanding their needs and problems. This is similar to the servant leadership model, which states that servant leaders must be committed to listening to followers' needs and seeks to identify the will of the group. Furthermore, a servant leader must be able to empathize with his/her followers, show respect, and be accepting to the behaviors of coworkers. As Spears [19] concluded, "the most successful servant leaders are those who have become skilled empathetic listeners" (p. 27), this is in line with the service leadership model. In general, both service and servant leadership theories share the notion that the personal qualities of leaders are crucial in effective leadership; they also recognize the interactive relationship between leaders' characteristics and the needs of the organization/ followers [20]. 
Furthermore, according to the service leadership model, leadership is not confined to certain individuals. In fact, everyone can, or has the potential to, become a leader. While servant leadership theory does not explicitly highlight that everyone is a leader, proponents do acknowledge that servant leadership qualities may be inherent within many individuals, and these tendencies can be enhanced through learning and practice [19]. Whether leadership skills can be developed depends on leaders' motivation [21] and self-leadership to a great extent. The service leadership model emphasizes selfleadership, asserting that individuals must be able to effectively engage in self-management, self-reflection, as well as constant monitoring and evaluation of goal attainment in order to succeed in leading others. The notion of self-leadership, however, has not been mentioned in the servant leadership literature. Self-leadership is important for service leaders, as it acts as a motivation to seek for continuous improvement.

In the service leadership model, it is asserted that service leaders should have "the humility of recognizing that achieving goals is not as easy as stating them" [3] and only with consistent improvements can one actualize their goals. In comparison, servant leadership does not talk about the continuous improvement of leaders per se, but again, focuses merely on the growth of followers. Servant leaders' role is to be committed to the development of followers, such as other employees within an organization [19]. Indeed, both service and servant leadership theories value the development of followers, particularly through mentoring and teaching. A successful servant leader should be able to mentor followers through empowerment, and by providing encouragement and support to mentees. According to Greenleaf, a question that servant leaders should ask themselves is whether their followers are equipped to become servant leaders themselves. To achieve an affirmative answer, servant leaders must form a mentoring relationship with their followers [22].

Another distinguishing characteristic of service leadership is the incorporation of Chinese cultural values in its theorization. In comparison, the servant leadership theory was first developed in the West. In particular, some scholars introduced servant leadership with reference to teachings of Jesus Christ [23] asserting that "it was Christianity's founder, Jesus Christ, who first taught the concept of servant leadership" (p. 58).

Finally, in terms of comprehensiveness and breadth of the two theories, service leadership adopts a more holistic approach and highlights the importance of leadership competencies, and both intrapersonal and interpersonal skills of leaders. The model discusses the impact of emotional, behavioral, physical, cognitive, and spiritual elements to the success of leadership. In comparison, servant leadership is less comprehensive, with almost no mention of job/trade-specific leadership skills, and focuses mainly on leaders' attitude of service toward followers [24].

\section{Spiritual leadership}

Spiritual leaders are those who possess "the values, attitudes, and behaviors that are necessary to intrinsically motivate one's self and others so they have a sense of spiritual survival/well-being through calling and membership" [25, p. 4]. Spiritual leadership is achieved through leaders' creation of a vision, establishment of an organizational culture based on altruistic love and the encouragement of hope and faith. In terms of service orientation, the definition above clearly shows that spiritual leadership, like service leadership, acknowledges the importance of satisfying the mutual needs of both oneself and followers. The value of transcendence central to spiritual leadership encourages leaders to place the needs of followers above one's self-interest of obtaining extrinsic rewards of power, wealth, and prestige often associated with leadership. However, this does not mean that spiritual leaders should forgo all self-interests. Rather, through one's leadership role and work, he/she should seek satisfaction of their intrinsic needs for spiritual identity and fulfillment, such as finding meaning in one's work [26].

Similar to service leadership, spiritual leadership also adopts a systems orientation where the model includes components regarding leaders' and followers' needs and development, and addresses the importance of nurturing an environment of openness, fairness, individuality, and to create personal meaning and self-worth in relevance to the larger community. The spiritual leadership model holds a "community conception of the organization both as an economic enterprise and as a human system... [which] includes services that address the personal as well as the professional lives of workers" [26, p. 13], which acknowledges the systemic nature and interplay between one's leadership behaviors with the environment.

In terms of leadership competencies, unlike service leadership, the spiritual leadership model is less concerned about functional abilities of leaders. According to Day [27], spiritual leadership focuses on the collective social influence process between leaders and followers, as opposed to the development of leaders' knowledge, skills, and abilities. The service leadership model includes a more exhaustive list of leadership competencies, such 
as communication, conflict management and problemsolving skills, which are seldom discussed in spiritual leadership texts.

In terms of moral character, many of the defining attributes of spiritual leadership carry a strong moral overtone, similar to service leadership. For instance, spiritual leaders must be courageous, have the mental and moral strength to uphold justice, and the spirit to prevail in times of adversity. In addition, they are expected to show high levels of integrity and honesty through their actions [28]. Furthermore, both service leadership and spiritual leadership theorists agree that leaders must possess a caring disposition. A core component of spiritual leadership is altruistic love, which is characterized by a genuine care and concern for oneself and others, exhibiting qualities of empathy, compassion, patience, and kindness.

In a study, Reave [29] reviewed over 150 studies and identified spiritual practices in leadership which stresses the importance of care. Reave gathered that expressing care, and showing support and individualized consideration for followers are practices emphasized in all spiritual paths. Listening responsively, respecting and appreciating others' contributions are also vital in spiritual leadership. In short, similar to service leadership, effective spiritual leadership is highly dependent upon the leader and the inner qualities of his/her human spirit, such as love, patience, tolerance, a sense of responsibility, and harmony [28].

With reference to the notion of whether anyone can be a leader, the literature on spiritual leadership does not provide a clear stance. However, an increasing number of organizations are trying to develop leaders who lead from spiritual values, resulting in more and more leaders seeking for spiritual fulfillment through leadership [26], which provides indirect evidence to suggest that everyone can be trained to become spiritual leaders. The quest for spirituality as a leader greatly depends on one's intrinsic motivation, which is central to self-leadership emphasized in the service leadership model. Although the specific terminology of "self-leadership" is not mentioned in spiritual leadership, the underlying notion of self-management and motivation is emphasized, as spiritual leaders' calling serves as a self-leading force for them to act in ways that help to benefit both oneself and their followers. Furthermore, qualities of altruistic love, such as forgiveness, compassion and patience, all require self-control, persistence, and refraining from the gratification of selfish intents [28]. In addition to altruistic love, Fairholm [26] also abstracted other effective spiritual leadership practices, including "the value of personal and other forms of development (growth) to become one's best self", and the "emphasis on continuing evaluation of progress” (p. 13), which aligns with service leadership's value on the pursuit of continuous improvement. Regarding mentoring, while service leadership model values the mentoring of followers, this is not highlighted in spiritual leadership.

While spiritual leadership shares similarities with the service leadership model, one of the greatest differences is its philosophical underpinning. While the service leadership model is developed from both Eastern and Western teachings, most spiritual leadership values, however, are drawn from principles of Judeo-Christian teachings [30], which reflect core values from the West [31].

Finally, in terms of comprehensiveness, the spiritual leadership model does specify the relations between levels of the theory (i.e. the leader, follower, community), which helps increase model comprehensiveness [32]. However, in comparison with the service leadership model that emphasizes holistic qualities, the 12 dimensions of a service leader place equal emphasis on one's cognitive, emotional, social, behavioral, and spiritual attributes, spiritual leadership theory focuses mainly on the spiritual dimension, downplaying the others critical dimensions.

\section{Authentic leadership}

Authentic leadership is defined "as a process that draws from both positive psychological capacities and a highly developed organizational context, which results in both greater self-awareness and self-regulated positive behaviors on the part of leaders and associates, fostering positive self-development" [33, p. 243]. In contrast to the focus on both the self and others in the service leadership model, authentic leadership model places great emphasis on leaders' self instead of the ecological systems. Effective authentic leadership is mostly influenced by leaders' personal history and dependent on one's capacity to engage in self related processes, such as self-reflection, self-awareness, and self-regulation [34]. Sparrowe [35] observed that "the emphasis in contemporary leadership on awareness of an interior, 'true' self has the unintended consequence of neglecting how the authentic self is constituted in relationship with others" (p. 421). In contrast to the systems orientation of service leadership, which adopts a multi-level perspective of leadership, authentic leadership theory is primarily conceptualized at the individual level, dealing with individual differences and their influences on leadership behaviors [36]. Furthermore, even in Yammarino et al.'s [36] formulation of authentic leadership as a multi-level construct, which proposes 
conceptualizations based on the individual (leader), leader-follower dyad, group/team and the organization, the notion of systems/habitat or the community is not explicitly addressed.

In terms of personal qualities, authentic leadership theory does not include discussions on leadership competencies. While the focus of service leadership is placed mainly on intrapersonal competencies of morality and caring disposition, authentic leaders are "perceived by others as being aware of their own and others' values/ moral perspectives, knowledge, and strengths; aware of the context in which they operate; and who are confident, hopeful, optimistic, resilient, and of high moral character" [37, p. 4]. Therefore, morality and integrity are also crucial components of the authentic leadership theory.

However, caring disposition is not highlighted in the model, although some authentic leadership theorists do discuss the importance of building trust through benevolence [38]. Similar to service leadership, authentic leadership focuses on the importance of personal qualities of leaders. Particularly, authentic leaders must possess positive psychological capacities of confidence, optimism, hope, and resilience [33]. Personal qualities, however, under the service leadership model, take on a more holistic person-approach (i.e. beyond positive organizational psychology frameworks) taking an integrated consideration of cognitive, psychological, and behavioral aspects of the leader.

While the service leadership model maintains that everyone has the potential and opportunity to take on leadership roles on a daily basis, authentic leadership literature does not explicitly state whether all individuals are inherent authentic leaders. Proponents of authentic leadership theory also agree on the malleability of leadership skills, claiming that authentic leadership can be developed through training [39]. However, the effectiveness of authentic training programs may yield differential outcomes depending on the targets' personality (e.g. emotional stability may impact the potential of certain individuals for becoming leaders) or age (e.g. one's experiences and abilities to reflect), which implies that not everyone's authentic leadership potential can be fully realized [40] Leaders' self-initiative may also play a role in authentic leadership development.

Although the term "self-leadership" is not directly referred to in authentic leadership, self-regulation and determination is a fundamental element. Authenticity of leaders are achieved by exerting self-control, setting internal standards, and continually assessing whether discrepancies exist between standards and behaviors, and identifying ways to narrow those gaps [41]. Although the search for continuous improvement is not a core component of authentic leadership, the theory has been developed based on teachings of humanistic psychologists, such as Maslow [42] and Rogers [43], who talk about self-actualization, alluding on human's inherent will for self-improvement.

The notion of mentoring is discussed in authentic leadership, where leaders influence followers through the process of "leading by example". Mentoring operates through positive modeling of authentic behaviors, such as self-awareness, moral actions, and positive psychological states [41]. Coaching and mentoring programs are effective tools in developing authentic leadership [44]. Regarding the philosophical root of authentic leadership, the notion of authenticity is rooted in Greek philosophy, and authentic leadership theory is derived from existential and humanistic psychology developed in the West. As such, Chinese cultural values are not components of the model. Finally, in terms of comprehensiveness and breadth of the models, authentic leadership research is mostly conducted in organizational settings centering its theoretical development on positive organizational psychology models, such as the psychological capital framework [33]. As such, authentic leadership is far less comprehensive compared with the service leadership model's applicability. In addition, authentic leadership emphasizes the psychological component of leadership, thus overlooking many other important leadership dimensions.

\section{Ethical leadership}

Ethical leadership is defined as "the demonstration of normatively appropriate conduct through personal actions and interpersonal relationships, and the promotion of such conduct to followers through two-way communication, reinforcement, and decision-making” [45, p. 120]. Similar to service leadership, which has a service orientation toward both the self and others, ethical leadership is thought to be transformational for both the self and follower [46]. Thus, it constitutes two dimensions, "moral persons" and "moral managers". Regarding service to the self, ethical leaders are "moral persons" concerned with consciously reflecting on and managing personal ethics while demonstrating normatively appropriate conduct when leading others. Leaders serve as "moral managers" to followers, and must constantly engage in open ethical discussions with followers, empowering them to seek justice and behave morally [47]. In terms of systems orientation, unlike the service leadership model that adopts a systemic approach, "the individual level of analysis 
(i.e. an individual leader) is largely assumed to be and generally discussed as the focal level of interest" [48, p. 407] in ethical leadership.

In terms of leadership competencies, some ethical leadership theorists delineated managerial competencies and task-specific skills, such as goal-directed orientation, proactive analytical, and problem-focused skills as resources required for leaders [46]. Service leadership and ethical leadership theories unequivocally agree that having great moral character (i.e. with positive attributes such as trustworthy, reliable, and credible) is important for leaders. As pointed out by Brown and Treviño [49], "ethical leaders are characterized as honest, caring, and principled individuals who make fair and balanced decisions” (p. 597). Compared with service leadership where caring disposition is a focal component, ethical leadership only briefly discusses the importance of being caring, as its distinguishing dimension lies in the ethical component. Regarding personal qualities of leaders, proponents of ethical leadership share similar views with service leadership theorists on its importance. In an extensive review on the ethical leadership literature, Brown and Treviño [49] outlined various individual characteristics (e.g. agreeableness, conscientiousness, motivation, high moral reasoning level) that enhance the attractiveness and credibility of ethical leaders.

Ethicalleadership theorists makeno apparent mention that everyone is an ethical leader, but do assert that everyone can be ethical leaders, as ethical leadership behaviors can be learned through role modeling and training or coaching sessions aimed at advancing moral reasoning skills and awareness [49]. Although explicit references to self-leadership are uncommon in ethical leadership literature, self-transformation has been identified as an important component of the model [50]. Self-transformation involves personal mastery, objective assessment, focused energies, persistence, patience and a creative desire for the future, which is similar to self-leadership processes entailing self-control, self-evaluation, goal-setting, and intrinsic motivation [51]. Ethical leadership theory is also concerned with the continuous growth of both leaders and followers. Ethical leaders and followers are expected to "continually expand their capacity to create the results they truly desire, where new and expansive patterns of thinking are nurtured... continually learning how to learn together" [52, p. 3]. In addition, ethical leadership theory is heavily influenced by the social learning theory [53]. Effective ethical leadership is achieved through ethical role modeling [47], where ethical leaders act as the main source of ethical guidance to followers [45]. As such, mentoring is also greatly valued under ethical leadership.
Ethical leadership theory is based on the social learning theory [53] and the social exchange theory [54], both of which are psychological theories developed in the West. Resick et al. [55] observed that "Confucian values are pervasive throughout societies in the Confucian Asian cluster. The conceptual model of components of ethical leadership... does not capture ethical values that are unique to those societies" (p. 356). Finally, in terms of comprehensiveness, Heslam et al. [56] argued that "all firms - large and small - need to pay attention to these four elements of social capital they create" (p. 17), i.e. spiritual, moral, relational, and institutional capital. "The intention to build each type of capital can provide multinationals with important guidance for decision-making” (p. 18). The ethical leadership model therefore is relatively less comprehensive as it is heavily skewed on the moral capital of leadership.

\section{Transformational leadership}

Transformational leadership refers to the process in which a leader moves a follower to perform in a manner that transcends self-interest and exceeds expectations of them. This is achieved through idealized influence (charisma), inspirational motivation, intellectual stimulation, or individualized consideration [57]. Transformational leadership is with the opposite of transactional leadership, which essentially features a leader-subordinate exchange. The transactional-transformational paradigm conceptualizes leadership dichotomously, as either a process involving followers' preoccupations with contingent extrinsic reinforcements (other service-oriented), or the influence of followers to forgo personal interests for the better of the collective (organization-oriented) [58]. Compared with service leadership that has a service orientation for both leaders and followers, transformational leadership's focus is mainly concerned with the interests of the collective. In terms of systems orientation, although transformational leadership does not cover the influence of the habitat or greater system as service leadership theory has, transformational leadership, to some extent, deals with leadership behaviors across levels, including leadership of small groups (micro-leadership), leadership of the organization (macro-leadership), and leadership of societies (meta-leadership) [58].

According to Chung [2, 5], effective service leadership is a function of leadership competencies, leaders' moral character, and a caring disposition. This is in stark contrast to the transformational leadership theory which does not include leadership competencies or caring disposition as 
core components of the model. Yukl [59] noted an obvious omission in transformational leadership of "task-oriented behavior relevant for effective leadership (e.g. clarifying expected results, setting specific task goals, operational planning, coordinating activities, allocating resources, monitoring operations in a non-obtrusive way)” (p. 290). The model is primarily concerned with leaders' charisma and motivational abilities [57]. However, morality is an important component given that transforming leaderfollower relationships should result in mutual stimulation where followers become leaders, and leaders become moral agents [60]. Transformational leaders are required to have a strong conviction in the moral righteousness of their values [60]. Similar to service leadership's emphasis on leaders' personal attributes, transformational leadership theorists have also listed several personal qualities of transformational leaders including high levels of pragmatism, self-confidence, nurturance, and low levels of aggressiveness [61].

Transformational leadership theory does not suggest whether all individuals can be leaders. However, proponents of the theory believe that everyone can be transformational leaders because transformational leadership behaviors can be trained [62] through training programs that have been proven to be effective [63].

Regarding self-leadership, unlike aforementioned leadership theories that share the importance of selfmanagement for effective leaders, this notion is seldom highlighted in the transformational leadership literature, especially not from the perspective of leaders. Though Avolio and Gibbons [64] argued that one of the aims of transformational leadership is to develop follower selfmanagement and self-development, this is not a focal component of the model. In service leadership, service leaders themselves are required to seek for continuous improvement in personal and professional development. However, this is not the main concern of the transformational leadership model. As a follower-centric leadership theory, transformational leaders are expected to motivate followers to seek for self-actualization and continuous improvement, rather than seeking improvement for themselves [65]. As such, similar to the service leadership model, transformational leaders are expected to influence followers and consider their individual needs for achievement by effectively coaching, mentoring, and providing support to them [66].

Transformational leadership theory was developed based on Burns' [60] conceptions of political leadership developed in the West. As such, Chinese cultural values have not been incorporated in the original formulation of the theory. However, Bass [67] later acknowledged that Confucian and Taoist traditions, which emphasize the responsibility of leaders in follower development, do share some similar ideologies with transformational leadership. The model is less comprehensive when compared with service leadership since transformational leadership is mainly concerned with the behavioral or social aspect of leadership, with little mention of emotional or spiritual components. However, studies have shown the transformational leadership paradigm to be applicable beyond organizational settings to include education, military and government settings and across cultures [58].

\section{Charismatic leadership}

Charismatic leadership occurs when followers attribute extraordinary qualities (i.e. charisma) to the leader. Some charismatic leadership behaviors include articulating innovative and idealized visions, displaying unconventional behaviors, and taking personal risks [68]. First, regarding service orientation, charismatic leadership is mostly oriented toward others, and less on the self. Charismatic leaders must be sensitive to the environment and the need of followers. Followers perceive leaders to be successful should they have the potential to satisfy their needs, and to take reformative actions even at the cost of personal risks and self-sacrifice [69]. Charismatic leadership theory is not conceptualized based on a systems model like service leadership. As Yukl [59] observed, charismatic leadership theories are mainly conceptualized at the dyadic level, in which organizational and systems level influences are rarely discussed.

With reference to leadership competencies, moral competencies and caring disposition, charismatic leadership states that leaders must possess in-role expertise and perform competently before followers could attribute charisma to them [70]. Moral competence is also a core component of the model. As charismatic leaders are expected to have moral conviction and concern for moral exercise of power [71], leaders' sensitivity to members' needs reflect the prerequisite of care and respect for followers [69] despite the fact that a caring disposition is not explicitly included as a main component of charismatic leadership. Similar to service leadership, charismatic leadership theory delineates personal qualities of leaders conducive for success, including prosocial assertiveness, self-confidence, critical, and encouraging [72].

Nevertheless, charismatic leadership has been criticized for its heroic leadership bias, where leadership effectiveness is overly determined by the skills and actions of leaders who possess particular traits [59]. This is 
contrasted with service leadership's assertion that leadership is not confined to those with particular skills, power or authority, but rather, everyone has the opportunity to become service leaders. The notion of self-leadership or similar leader motivational processes is non-evident in the charismatic leadership literature. Furthermore, the theory does not state whether charismatic leaders must seek continual improvement in their leadership. Instead, the model focuses on developing and empowering the followers. In addition, although the importance of mentoring is not explicitly delineated as a focal component of the model, charismatic leaders stimulate followers to challenge the status quo and creatively devise problem solving methods through coaching. Charismatic leaders often act as role models to their followers [73].

The notion of charisma was built on teachings in the Bible, and the model was developed from earlier works of sociologist Max Weber [74]. Thus, Chinese cultural values are not part of the model. Finally, charismatic leadership is less comprehensive than service leadership, as the former focuses on leadership behavior only, and other important dimensions are not mentioned in the model. In addition, the model's applicability has been limited to organizational settings [75].

\section{Top-down leadership}

Traditionally, leadership is conceptualized as top-down influence from leaders with power (i.e. formally appointed individuals who are high in the organizational hierarchy) to those who hold lower positions in the bureaucracy. It is also known as vertical leadership, since important decisions are made by a single "heroic" leader and influence is unilateral [76]. In fact, the layman's notion of leadership is commonly framed in terms of the vertical leadership model. As contrasted with the service leadership's consideration of satisfying both the needs of the self and others, vertical leadership theory is mostly concerned with the behaviors and mindsets of leaders alone [76]. Regarding systems orientation, vertical leadership theory has been critiqued for ignoring leadership dynamics within a group context [77]; influences of the habitat and larger system on leadership behaviors are not the emphasis of the model.

Top-down leadership models clearly distinguish between the roles and responsibilities of leaders and workers, managerial related competencies of command and control are focal components of the model [78]. Given that effective top-down leadership is evidenced by indicators, such as output efficiency, procedure adherence and defect rates [79], as opposed to quality of leader-follower relationships, the personal qualities, moral character, and caring disposition are not focal components of the theory.

One of the distinguishing features of vertical leadership is its dependency on the wisdom of a single individual leader of an organization [78], which is in contrast with the notion that everyone is or can be leaders as advocated by the service leadership model. Self-leadership as a changing concept of leadership is not mentioned in the model. Similarly, the need for leaders to seek continual improvement is not a concern of the theory. Top-down leaders exert influence on followers through control. Mentoring requires communication with and empowerment of followers and may narrow the power distance relationship between leaders and followers, which contradict with the mechanism of the model; hence, it is not a part of the model.

Vertical leadership theory was developed during the Industrial Revolution and can be considered deeply rooted in Western history [78]. As such, Chinese cultural values are not included in the model. Finally, top-down leadership model was favored during the industrial era where environments were less dynamic and required fewer demands on the cognitive, emotional, and spiritual capabilities of leaders. This resulted in the development of a model that is less comprehensive than the service leadership model developed to serve the needs of contemporary knowledge-based and complex economies.

\section{Limitations of the service leadership model}

From Table 2, it is obvious that there are several unique features of the service leadership model. Nevertheless, as an evolving leadership model, there are several limitations of the model. First, documentation of the service leadership model is still thin. As such, it would be helpful if more publications on the theoretical details of the model could be produced. The publication of the "Bible" would help colleagues to further understand the postulations of the service leadership model. Second, some of the concepts in the model require further elaboration. For example, the basis of moral character in the model should be clarified. Why do service leaders need to have moral character? Do they do this out of instrumental reasons or ideological reason? The same query applies to caring disposition. Why do service leaders need to care about others? Third, as Chinese cultural values are proposed in the model, how can these be integrated with other leadership qualities based on the Western models require some thoughts. In fact, as a start, more rigorous definitions 
of Chinese cultural values, such as Confucian virtues, require conceptual as well as operational definitions is in order.

Fourth, more research on the service leadership model is needed. There are several areas requiring more exploration. Primarily, there is a need to understand the determinants of effective service leadership qualities, such as developmental history and contextual factors. Moreover, the inter-relationship amongst effective service leadership, including leadership competencies, moral character, and caring disposition should be empirically examined. Furthermore, the outcomes of service leadership qualities deserve further research. Essentially, do these leadership qualities lead to better services provided to the service recipients? Do they lead to greater organizational effectiveness? Do they help a service leader develop as a leader and as a person? One important limitation of the service leadership model is that it utilizes the research from disciplines without generating its own research findings.

Fifth, as there is a severe lack of service leadership curricula, it is important to conduct research on the development of a training program on service leadership. With the support of the Victor and William Fung Foundation, eight universities supported by the University Grants Committee are now working on the service leadership curricula. Aside from considering what should be included in service leadership training, evaluation studies on the effectiveness of the training programs and related curriculum should be gradually carried out as well.

\section{Reflections and future research directions}

The service leadership model considers the complexity of the service context against Hong Kong's service-oriented background, along with the role of culture in leadership. The ideologies behind the service leadership model fuse teachings, research, and experiences from the West and the East, including Confucian, Buddhism, and Taoism doctrines. However, incorporating the elements of culture in the development of the model can sometimes be a twoedged sword. On the one hand, as most existing leadership theories are developed in the West, the service leadership model being developed in an Asian context serves as an informative addition to the leadership literature. On the other hand, the generalizability of the leadership model across cultures may be questioned [80]. Thus, cross-cultural research is warranted to investigate the applicability of the service leadership model in other Western and even Asian contexts.

Moreover, currently, the service leadership model does not specify situational variables that may moderate service leadership behaviors and impact on its underlying processes. For instance, what are the facilitating and hindering conditions to service leadership? Indeed, the service leadership model and its research are still in its infancy. Therefore, questions regarding the antecedents and consequences of service leadership, and its underlying psychological processes are yet to be answered. In order to stimulate research in this area, a valid and reliable measure of service leadership must first be developed to equip researchers with a tool for investigation. Field experiments and observations can also be conducted to examine the causal effects of service leadership behaviors on organizational outcomes.

Despite the above limitations, the service leadership model is a comprehensive model that has been developed based on extensive research from multi-disciplines and incorporates traditional ideologies from both the East and West. Most importantly, the model conceptualizes effective leadership based on the needs of the current service economy and serves as an important contribution to the existing leadership literature for scholars, educators, and practitioners.

\section{References}

1. Shek DT, Chung PP, Leung H. Manufacturing economy vs. service economy: Implications for service leadership. Int J Disabil Hum Dev 2015;14:205-15.

2. Chung P. Distinguishing characteristics of service leadership and management education. Hong Kong Institute of Service Leadership and Management; 2010. Available at: http://hkislam.org/index.php? $r=$ article\&catid=2\&aid $=29$.

3. Chung $P$. The 25 Principles of service leadership. In press.

4. Chung P. Your second skin. Managing the 12 dimensions of your personal brand for the service age. In press.

5. Chung P. Service reborn. Hong Kong: Lexingford Publishing, 2012.

6. Kirkpatick SA, Locke EA. Leadership: do traits matter? Acad Manage Exec 1991;5:48-60.

7. Barker RA. The nature of leadership. Hum Relat 2001;54: 469-94.

8. Saal FE, Knight PA. Industrial-organizational psychology: science and practice. Pacific Grove, CA: Brooks/Cole Publishing, 1988.

9. Riegel KF. Towards a dialectic theory of development. Hum Dev 1975;18:50-64.

10. Dweck CS, Leggett EL. A social-cognitive approach to motivation and personality. Psychol Rev 1988;95:256-73.

11. Roberts DC. Student leadership programs in higher education. Carbondale, IL: Southern Illinois University Press, 1981. 
12. Brungardt $C$. The making of leaders: a review of the research in leadership development and education. J Leadership Organ Stud 1997:3:81-95.

13. Bakan D. Origination, self-determination, and psychology. J Humanist Psychol 1996;36:9-20.

14. Resnick S, Warmoth A, Serlin IA. The humanistic psychology and positive psychology connection: implications for psychotherapy. J Humanist Psychol 2001;41:73-101.

15. Greenleaf RK. Servant leadership: a journey into the nature of legitimate power and greatness. USA: Paulist Press, 1977.

16. Fry LW, Matherly LL, Whittington JL, Winston BE. Spiritual leadership as an integrating paradigm for servant leadership. In: Singh-Sengupta S, Fields D, editors. Integrating spirituality and organizational leadership. Delhi: Macmillan India, 2007:70-82.

17. van Dierendonck D. Servant leadership: a review and synthesis. J Manage 2011;37:1228-61.

18. Russell RF, Stone AG. A review of servant leadership attributes: developing a practical model. Leadership Organ Dev J 2002;23:145-57.

19. Spears LC. Character and servant leadership: ten characteristics of effective, caring leaders. J Virtues Leadership 2010;1:25-30.

20. McGregor D. The human side of enterprise. New York: McGraw-Hill Book Co., 1960.

21. Mumford MD, Zaccaro SJ, Johnson JF, Diana M, Gilbert JA, Threlfall KV. Patterns of leader characteristics: implications for performance and development. Leadership Quart 2000;11:115-33.

22. Poon R. A model for servant leadership, self-efficacy and mentorship. Proceedings of the Servant Leadership Research Roundtable. 2006 Aug; Virginia Beach, VA: Regent University.

23. Sendjaya S, Sarros JC. Servant leadership: Its origin, development, and application in organizations. J Leadership Organ Stud 2002;9:57-64.

24. Reinke SJ. Service before self: towards a theory of servantleadership. Global Virtue Ethics Rev 2004;5:30-57.

25. Fry LW, Matherly LL. Spiritual leadership and organizational performance: an exploratory study. Paper presented at: Academy of management meeting, Atlanta, Georgia, 2006.

26. Fairholm GW. Spiritual leadership: fulfilling whole-self needs at work. Leadership Organ Dev J 1996;17:11-7.

27. Day DV. Leadership development: a review in context. Leadership Quart 2000;11:581-613.

28. Fry LW. Toward a theory of spiritual leadership. Leadership Quart 2003;14:693-727.

29. Reave L. Spiritual values and practices related to leadership effectiveness. Leadership Quart 2005;16:655-87.

30. Erteszek JJ. The common venture enterprise: a Western answer to the Japanese art of management? New Manage 1983;1:4-10.

31. Fairholm GW. Values leadership: toward a new philosophy of leadership. New York: Praeger, 1991.

32. Klein KJ, Dansereau F, Hall RJ. Levels issues in theory development, data collection, and analysis. Acad Manage Rev 1994;19:195-229.

33. Luthans F, Avolio BJ. Authentic leadership: a positive developmental approach. In: Cameron KS, Dutton JE, Quinn RE, editors. Positive organizational scholarship. San Francisco, CA: BarrettKoehler, 2003:241-61.

34. Gardner WL, Avolio BJ, Luthans F, May DR, Walumbwa F. Can you see the real me? a self-based model of authentic leader and follower development. Leadership Quart 2005;16:343-72.
35. Sparrowe RT. Authentic leadership and the narrative self. Leadership Quart 2005;16:419-39.

36. Yammarino FJ, Dionne SD, Schriesheim CA, Dansereau F. Authentic leadership and positive organizational behavior: a meso, multi-level perspective. Leadership Quart 2008;19:693-707.

37. Avolio BJ, Luthans F, Walumbwa FO. Authentic leadership: theory-building for veritable sustained performance. Working paper. Gallup Leadership Institute, University of Nebraska, Lincoln, 2004.

38. Avolio BJ, Gardner WL, Walumbwa FO, Luthans F, May DR. Unlocking the mask: a look at the process by which authentic leaders impact follower attitudes and behaviors. Leadership Quart 2004;15:801-23.

39. Shamir B, Eilam G. "What's your story?” a life-stories approach to authentic leadership development. Leadership Quart 2005;16:395-417.

40. Cooper CD, Scandura TA, Schriesheim CA. Looking forward but learning from our past: potential challenges to developing authentic leadership theory and authentic leaders. Leadership Quart 2005;16:475-93.

41. Avolio BJ, Gardner WL. Authentic leadership development: getting to the root of positive forms of leadership. Leadership Quart 2005;16:315-38.

42. Maslow A. Motivation and personality, 3rd ed. New York: Harper, 1968.

43. Rogers CR. Actualizing tendency in relation to "motives" and to consciousness. In: Jones MR, editor. Nebraska symposium on motivation. Oxford, England: University of Nebraska Press, 1963:1-24.

44. Ilies R, Morgeson FP, Nahrgang JD. Authentic leadership and eudaemonic well-being: understanding leader-follower outcomes. Leadership Quart 2005;16:373-94.

45. Brown ME, Treviño LK, Harrison DA. Ethical leadership: a social learning perspective for construct development and testing. Organ Behav Hum Dec 2005;97:117-34.

46. Mendonca M. Preparing for ethical leadership in organizations. Can J Adm Sci 2001;18:266-76.

47. Treviño LK, Hartman LP, Brown M. Moral person and moral manager: How executives develop a reputation for ethical leadership. Calif Manage Rev 2000;42:128-42.

48. Palanski ME, Yammarino FJ. Integrity and leadership: a multilevel conceptual framework. Leadership Quart 2009;20: 405-20.

49. Brown ME, Treviño LK. Ethical leadership: a review and future directions. Leadership Quart 2006;17:595-616.

50. Kanungo RN, Mendonca M. Ethical dimensions of leadership. London: Sage Publications, 1996.

51. Manz CC. Self-leadership: toward an expanded theory of self-influence processes in organizations. Acad Manage Rev 1986;11:585-600.

52. Senge PM. The fifth discipline: the art and practice of the learning organization, rev ed. London: Century Business, 2006.

53. Bandura A. Social foundations of thought and action: a social cognitive theory. Englewood Cliffs, NJ: Prentice-Hall Inc., 1986.

54. Blau PM. Exchange and power in social life. New York: John Wiley, 1964. 
55. Resick CJ, Hanges PJ, Dickson MW, Mitchelson JK. A crosscultural examination of the endorsement of ethical leadership. J Bus Ethics 2006;63:345-59.

56. Heslam P, Jones I, Pollitt M. How a social capital approach can help multinationals show ethical leadership. Cambridge: Centre for Business Research, University of Cambridge, 2009.

57. Bass BM. A new paradigm for leadership: an inquiry into transformational leadership. Alexandria, VA: US Army Research Institute Behavioral Social Sciences, 1996.

58. Bass BM. Does the transactional-transformational leadership paradigm transcend organizational and national boundaries? Am Psychol 1997;52:130-9.

59. Yukl G. An evaluation of conceptual weaknesses in transformational and charismatic leadership theories. Leadership Quart 1999;10:285-305.

60. Burns JM. Leadership. New York: HarperCollins, 1978.

61. Ross SM, Offermann LR. Transformational leaders: measurement of personality attributes and work group performance. Pers Soc Psychol B 1997;23:1078-86.

62. Bass BM, Avolio BJ. Developing transformational leadership: 1992 and beyond. J Eur Ind Training 1990;14:21-37.

63. Barling J, Slater F, Kelloway EK. Transformational leadership and emotional intelligence: an exploratory study. Leadership Organ Dev J 2000;21:157-61.

64. Avolio BJ, Gibbons TC. Developing transformational leaders: a life span approach. In: Conger JA, Kanungo RN, editors. Charismatic leadership: the elusive factor in organizational effectiveness. San Francisco, CA: Jossey-Bass, 1988:276-308.

65. Dvir T, Eden D, Avolio BJ, Shamir B. Impact of transformational leadership on follower development and performance: a field experiment. Acad Manage J 2002;45:735-44.

66. Bass BM, Riggio RE. Transformational leadership. 2nd ed. Mahwah, NJ: Lawrence Erlbaum, 2005.

67. Bass BM. Leadership and performance beyond expectations. New York: Free Press, 1985.

68. Conger JA, Kanungo RN. Charismatic leadership in organizations. Thousand Oaks, CA: Sage, 1998.
69. Conger JA, Kanungo RN, Menon ST. Charismatic leadership and follower effects. J Organiz Behav 2000;21:747-67.

70. Crant JM, Bateman TS. Charismatic leadership viewed from above: the impact of proactive personality. J Organiz Behav 2000;21:63-75.

71. House RJ, Howell JM, Shamir B, Smith B, Spangler WD. The theory of charismatic leadership: extensions and evidence. Philadelphia, PA: Reginald H. Jones Center for Management Policy, Strategy, and Organization, Wharton School, University of Pennsylvania, 1994.

72. Bass BM. Evolving perspectives on charismatic leadership. In: Conger JA, Kanungo RN, editors. Charismatic leadership: the elusive factor in organizational effectiveness. San Francisco, CA; Jossey-Bass, 1988:40-77.

73. Waldman DA, Yammarino FJ. CEO charismatic leadership: levelsof-management and levels-of-analysis effects. Acad Manage Rev 1999;24:266-85.

74. Weber M. The theory of social and economic organization. In: Henderson AM, Parsons T, translators. New York: Oxford University Press, 1947.

75. Conger JA, Kanungo RN. Toward a behavioral theory of charismatic leadership in organizational settings. Acad Manage Rev 1987;12:637-47.

76. Pearce CL, Conger JA. All those years ago: the historical underpinnings of shared leadership. In: Pearce CL, Conger JA, editors. Shared leadership: reframing the hows and whys of leadership. Thousand Oaks, CA: Sage, 2003:1-18.

77. Barry D. Managing the bossless team: lessons in distributed leadership. Organ Dyn 1991;20:31-47.

78. Pearce CL, Manz CC. The new silver bullets of leadership: the importance of self-and shared leadership in knowledge work. Organ Dyn 2005;34:130-40.

79. Macpherson M. Performance measurement in not-for-profit and public-sector organizations. Measuring Bus Excellence 2001;5:13-7.

80. Avolio BJ. Promoting more integrative strategies for leadership theory-building. Am Psychol 2007;62:25-33. 